\title{
ВПЛИВ РЕЖИМІВ РУХУ МІСЬКИХ АВТОБУСІВ НА ПАЛИВНУ ЕКОНОМІЧНІСТЬ ТА ЕКОЛОГІЧНУ БЕЗПЕКУ
}

\begin{abstract}
В роботі обгрунтована актуальність дослідження впливу режимів руху міських автобусів на паливну економічність та екологічну безпеку. Виконано аналіз робіт, які присвячені питанням визначення витрат палива 1 динамічних якостей автомобілів. Встановлено, що для міських автобусних перевезень найбільш вагомими факторами, які впливають на паливну економічність є довжина перегону і наповнення салону автобусу. Розроблена розрахункова модель, яка дозволяє дослідити вплив умов експлуатації на процес формування витрат палива міськими автобусами. На підставі результатів обстеження пасажиропотоків на маршруті №34 були розраховані витрати палива для автобусів Богдан А092 для різних режимів руху. Наведені результати експериментальних досліджень, які підтверджують адекватність розробленої розрахункової моделі. безпека.

Ключові слова: витрати палива, довжина перегону, режим руху, розрахункова модель, екологічна
\end{abstract}

Постановка проблеми. На сьогоднішній день міський автобусний транспорт стає все більш соціально орієнтованим, оскільки основними пасажирами є люди з доходами нижче середнього рівня. Таким чином, в сучасних складних економічних умовах основною задачею АТП є виявлення таких варіантів організації перевезень на маршрутах, які призводили $б$ до мінімальних витрат, максимальної продуктивності рухомого складу, але в той же час враховували базові показники якості перевізного процесу пасажирів [1].

Незважаючи на певну бюджетну підтримку ефективність роботи міського пасажирського транспорту в містах залишається низькою. Недостатність коштів на оновлення (утримання) рухомого складу, стихійне формування маршрутної мережі, велика нерегульована конкуренція між офіційними та нелегальними перевізниками призводить до збитковості або низької рентабельності більшості АТП, в тому числі і у м. Дніпро. Наприклад у березні 2018 року пасажирські перевізники м. Дніпро намагаючись домогтися підвищення тарифу від органів міської влади були вимушені оприлюднити калькуляції собівартості перевізного процесу на маршрутах, які вони обслуговують [2]. Аналіз наданої величини розрахункового тарифу засвідчує, що більшість АТП вважають його економічно обгрунтованим, якщо він буде встановлений в діапазоні від 8 до 10 грн., а біля 15\% - від 10 до 15 грн. Одним із основних об'єктивних факторів, які призводять до суттєвого зростання тарифів є висока вартість палива, а на сам перед його велика питома вага у загальній калькуляції собівартості перевізного процесу. Так згідно 3 [2] витрати на паливо по провідним АТП м. Дніпро становлять від 43 до 59\% при середньому значенні у 48\%. На думку авторів такі значення пояснюються в першу чергу тим фактом, що 93\% маршрутів експлуатуються в режимі маршрутного таксі. Внаслідок цього водії (в умовах некерованої конкуренції), намагаючись зібрати якомога більше пасажирів, постійно роблять різкі прискорення і гальмування (особливо у центральній частині міста) кожні 50-100 м. Звичайно постійний рух автобусів у режимі 1-2 передачі призводить до суттєвого зростання витрат палива. Слід зазначити, що витрати на паливо на маршрутах, які працюють у звичайному режимі, становлять $34 \%$.

Одним із способів, який дозволяє суттєво скоротити витрати на паливо-мастильні матеріали (ПММ), а також сприяє зниженню кількості шкідливих викидів в атмосферу міста, є організація на міських автобусних маршрутах експресного сполучення [1]. Даний захід дозволяє скоротити витрати часу пасажирів на пересування та підвищити ефективність використання рухомого складу [3]. Оскільки експресні автобуси мають менше зупинок на шляху прямування ніж ті, які експлуатуються у звичайному режимі (тим більше ніж ті, що працюють у режимі маршрутного таксі), відповідно вони менше здійснюють гальмувань і розгонів, що сприяє значному зменшенню витрат на паливо.

Але на сьогоднішній день Міністерство інфраструктури України рекомендує здійснювати облік споживання ПММ за методикою [4], яка базується на відомостях про базову лінійну норму витрат палива транспортного засобу та низки коригуючих коефіцієнтів. Для міських автобусних перевезень використовують наступні поправки: робота в міських умовах (до 15\%), робота, яка потребує частих зупинок - 10\% та вік автобусу (до 9\%). Звичайно, такий якісних підхід не може враховувати всього різноманіття факторів, які впливають на ефективність перевізного процесу пасажирів. Тим більше не 
дає змоги оцінити перевізникам економічні переваги експресного режиму сполучення та застерегти від експлуатації автобусів у режимі маршрутного таксі, особливо у центральній частині міста.

Аналіз останніх досліджень. Питанням визначення паливної економічності і динамічних якостей автомобілів присвячені чисельні роботи таких вітчизняних та зарубіжних науковців як Говорущенко Н.Я. [5], Нефьодов А.Ф., Кузнецов С.С., Волков В.П., Кривошапов С.І., Абрамов С.Н. [6], Фалькевич Б.С, Веліканов Д.П., Кравець Н.Н., Корякін А.А. та багатьох інших вчених.

Але слід зауважити, що більшість із існуючих досліджень присвячені аналізу впливу конструктивних особливостей і технічного стану транспортних засобів (в переважній більшості вантажних та спеціалізованих автомобілів) на паливну економічність. Таким чином, розроблені на їх базі розрахункові моделі не можуть враховувати технологічних особливостей режимів руху автобусів в міських умовах. На думку авторів слід окремо відзначити роботу [6], в якій наведені результати впливу окремих параметрів організації руху автобусів на міських маршрутах на витрати палива. В результаті проведених експериментальних досліджень встановлено, що для міських автобусних перевезень найбільш вагомими факторами, які впливають на паливну економічність $є$ :

- довжина перегону (частота технологічних зупинок);

- наповнення салону автобусу;

- допустима швидкість руху на перегоні;

- геометрія дорожнього полотна.

Але отримані результати [6] не можуть бути застосовані для кількісного аналізу впливу режимів руху міських автобусів на витрати палива в сучасних умовах, бо, по-перше, вони були отримані для моделей автобусів, які вже не експлуатуються; а, по-друге, умови руху в сучасних містах України суттєво відрізняються від тих, які аналізувалися в роботі [6].

Формування цілей роботи. Незважаючи на різноманіття робіт присвяченим дослідженню паливної економічності транспортних засобів, питання формування норм витрат палива автобусами залишається маловивченим. У зв'язку з чим, проведення досліджень в області вивчення впливу умов експлуатації на процес формування витрат палива міськими автобусами є актуальною науковопрактичної задачею. Метою даної роботи $є$ розробка розрахункової моделі (із подальшою ії апробацією на типовому міському автобусному маршруті м. Дніпро), яка дозволить дослідити вплив режимів руху міських автобусів на паливну економічність та екологічну безпеку.

Матеріал і результати досліджень. Однією з найважливіших характеристик автомобіля, яка істотно впливає на собівартість перевізного процесу, $є$ його паливна економічність. Паливну економічність двигуна оцінюють питомою або годинної витратою палива. А транспортного засобу дорожніми витратами палива (на 100 км шляху) при різних режимах руху: на швидкості 40 км/год., 60 км/год., 90 км/год., 120 км/год.; при експлуатації в умовах міського, магістрального або змішаного їздових циклів. Їздовий цикл - це послідовний циклічний перехід режиму холостого ходу на режим розгону, сталої роботи та гальмування.

При згорянні палива в циліндрах двигуна виникає тиск газів $\left(p_{i}\right)$, який при впливі на поршні створює індикаторний момент $\left(M_{i}\right)$, величина якого прямо пропорційна середньому тиску газів в циліндрах двигуна і його робочому об'єму $\left(i \cdot V_{h}\right)$. Індикаторний момент витрачається на подолання всіх видів втрат, наявних в автомобілі: механічних втрат у двигуні $\left(P_{M}\right)$; втрат на привід допоміжного обладнання $\left(P_{\tau}\right)$; втрат в трансмісії $\left(P_{m p}\right)$; опору коченню шин $\left(P_{f}\right)$; аеродинамічного опору $\left(P_{w}\right)$.

Частина $M_{i}$, що залишилася представляє собою запас тяги $\left(P_{T}\right)$, який може бути витрачений на подолання підйомів $\left(P_{\alpha}\right)$ і сил інерції $\left(P_{j}\right)$. Перераховані показники, наведені до коліс автомобіля ( $\left.P_{T}\right)$, формують його силовий баланс [5]:

$$
\frac{p_{i} \cdot i \cdot V_{h}}{4 \pi} \cdot \frac{U_{m p}}{r_{K}}=P_{M}+P_{\tau}+P_{m p}+P_{f}+P_{w}+P_{j}+P_{\alpha}
$$

де $U_{m p}$ - передаточне число трансмісії; $r_{K}$ - радіус кочення коліс. 
Сукупність складових витрат палива, які витрачаються на подолання сил опору руху автомобіля, утворюють паливний баланс:

$$
Q_{s}=\frac{g_{i s}}{\rho} \cdot\left(P_{M}+P_{\tau}+P_{m p}+P_{f}+P_{w}+P_{j}+P_{\alpha}\right),
$$

де $\rho$ - щільність палива, г/л; $g_{i s}$-значення питомих індикаторних витрат палива, г/Н·100 км:

$$
g_{i s}=g_{i s \min }+\mu_{g} \cdot\left(\frac{4 \pi \cdot P_{i} \cdot r_{K}}{i \cdot V_{h} \cdot U_{m p}}-p_{0}\right)^{2}+\beta_{g} \cdot\left[\left(\frac{U_{m p} \cdot V}{r_{K}}\right)^{2}-\omega_{0}^{2}\right],
$$

де $g_{\text {is min }}$ - мінімальне значення питомих індикаторних витрат палива, г/Н·100 км; $\mu_{g}-$ коефіцієнт, який враховує зміну $g_{\text {is }}$ від $p_{i} ; \beta_{g}$ - коефіцієнт, який враховує зміну $g_{\text {is }}$ від $\omega ; p_{0}-$ точка перегину залежності $g_{i s}=f\left(p_{i}\right)$; $\omega_{0}$ - точка перегину залежності $g_{i s}=f(\omega)$; $\omega$ - кутова швидкість вихідного вала двигуна.

Базові залежності для визначення складових (1-3); розрахунку зовнішньої, швидкісної характеристики двигуна; шляхів, який проїжджає автомобіль під час прискорень та гальмувань досить повно описані в [5] і тому в роботі не наводяться. Розрахункова модель була створена у середовище Microsoft Excel.

Руху автобусів по міському маршруту характеризується циклічністю режимів (розгін $\rightarrow$ рівномірний рух $\rightarrow$ накат $\rightarrow$ гальмування) і високою динамічністю навантаження, яке пов'язано із великою інтенсивністю пасажирообміну на зупиночних пунктах. Для дослідження впливу режимів руху автобусів на їх паливну економічність та екологічну безпеку (а також апробації створеної розрахункової моделі) був обраний міський маршрут №34 (пр. Д. Яворницького - м/н Корея). Довжина маршруту становить 12,7 км, на маршруті облаштовано 26 зупиночних пунктів (відстані між якими відповідають звичайному режиму руху), на маршруті експлуатуються автобуси Богдан А092 у режимі маршрутного таксі.

Згідно із [4] базова лінійна норма витрат палива для автобусів Богдан А092 становить 16,1 л/100км. Розрахуємо експлуатаційні нормативні витрати палива згідно з цією методикою:

$Q_{H}=0,01 \cdot H_{Л} \cdot S \cdot\left(1+0,01 \cdot\left[K_{M У}+K_{\text {Чз }}+K_{\text {ВIК }}\right]\right)=0,01 \cdot 16,1 \cdot 100 \cdot(1+0,01 \cdot[15+10+9])=21,6$ л/100км,

де $H_{Л}$ - базова лінійна норма витрати палива, л/100 км; $S$ - пробіг автомобіля, км; $K_{M У}, K_{43}$, $K_{B I K}$ - коефіцієнти коригування відповідно: робота в міських умовах (для м. Дніпро 15\%), робота, яка потребує частих зупинок, 10\%; врахування віку або загального пробігу (понад 400 тис. - км 9\%).

На Рис. 1 наведені результати розрахунків значень витрат палива л/100км при розгоні (а) та контрольних витрат палива (б) при русі на відповідній передачі (1-6) для автобусу Богдан А092

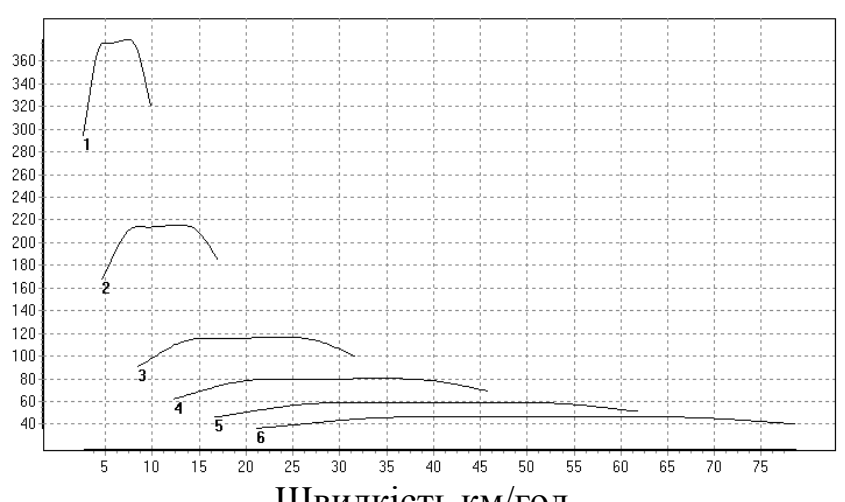

Швидкість км/год.

a)

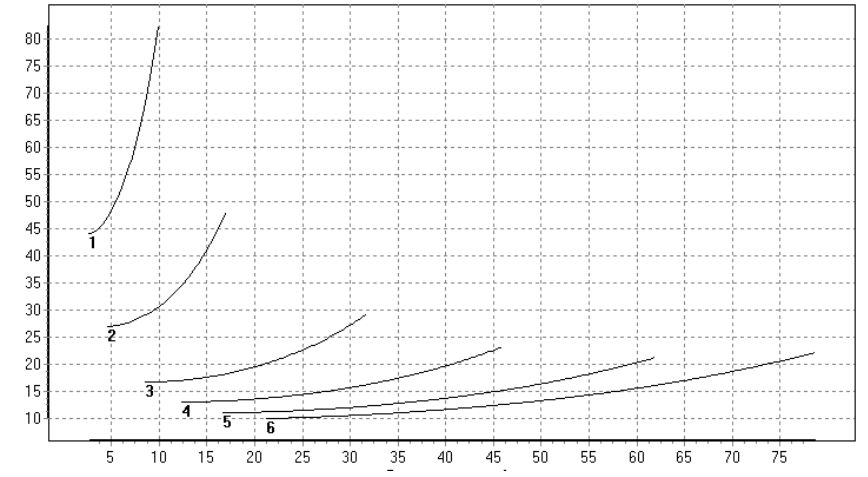

Швидкість км/год.

б)

Рисунок 1 - Розрахункові значення витрат палива л/100км при розгоні (а) та контрольних витрат палива (б) при русі на відповідній передачі (1-6) для автобусу Богдан А092 
Як було встановлено в роботі [6] найбільш вагомими факторами, які впливають на експлуатаційні витрати палива автобусів, є довжина перегону (частота технологічних зупинок) та наповнення салону автобусу. Для визначення реального розподілу кількості технологічних зупинок, а також додаткових динамічних навантажень, пов'язаних із перебуванням в салоні пасажирів, на маршруті №34 були проведенні обстеження пасажиропотоків табличним методом у ранкову годину «пік». Вірогідність пассажирообміну на зупиночних пунктах на маршруті №34 наведена на Рис. 2 (штрихуванням відмічені 26 стаціонарних зупинок). Взагалі протягом обстеження пассажирообмін спостерігався на 68 (в середньому на 46) зупинках.

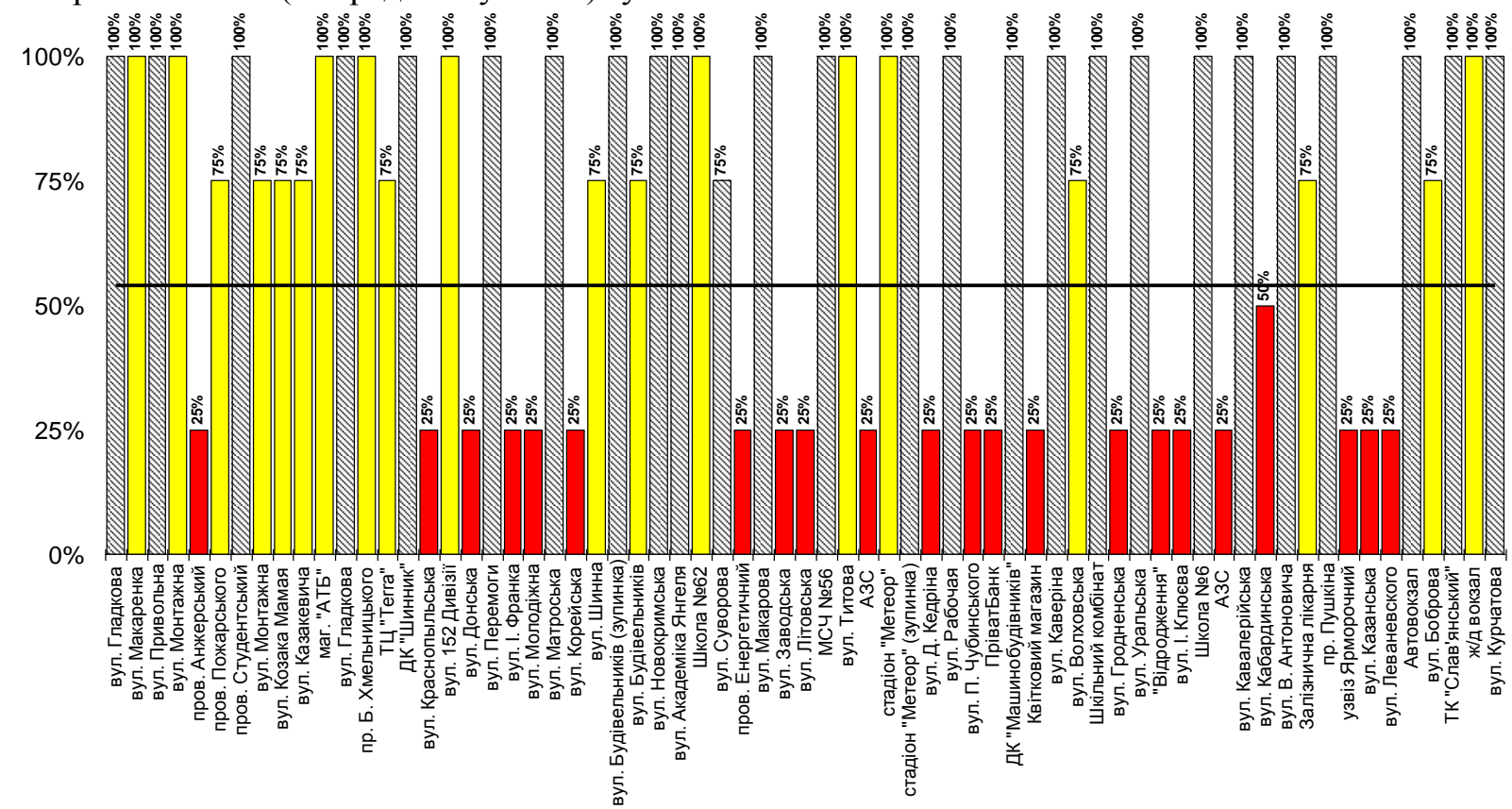

Рисунок 2 - Вірогідність пассажирообміну на зупиночних пунктах на маршруті №34

Кількість додаткових зупинок на світлофорах розраховувалась як середньозважене значення:

$$
M(e)=\sum_{e^{\epsilon} u} e \cdot P_{u}(e)=\sum_{e^{\epsilon} u} e \cdot\left(\frac{u !}{e ! \cdot(u-e) !}\right) \cdot p^{e} \cdot q^{u-e},
$$

де $e$ - кількість світлофорів на маршруті; $P_{u}(e)$ - вірогідність зупинки автобусів на $u$ світлофорах із $e, p$ - вірогідність зеленого сигналу світлофору; $q$ - вірогідність жовтого або червоного сигналу світлофору (вірогідності $p$ i $q$ розраховувались відповідно до тривалості фаз світлофорів).

Додаткові динамічні навантаження, пов'язані із перебуванням в салоні пасажирів, розраховувались як добуток наповнення автобусів, на відповідному перегоні, і середньої маси одного пасажира $\left(m_{\text {nac. }}=70 \mathrm{\kappa г,} \mathrm{[3])}\right.$

Отримані відомості про умови експлуатації роботи автобусів Богдан А092 на маршруті №34 були використані у якості вихідних даних для створеної розрахункової моделі (1-3). Результати моделювання витрат палива для 2, 4, 8 зупинок (експресний режим); 14, 26 зупинок (звичайний режим) та 46,68 зупинок (режим маршрутного таксі) наведені на Рис. 3. Аналіз інформації, наведеної на Рис. 3 , засвідчує, що витрати палива автобусів, яки працюють у звичайному режимі $\left(n_{\text {зуn }}=26, l_{\text {nep }}\right.$ $=0,51$ км) перевищують нормативні значення [4] на $36 \%$; а у режимі маршрутного таксі ( $n_{\text {зуn }}=46, l_{\text {nep }}$ $=0,28$ км) на $86 \%$. На думку авторів даний факт пояснюється, по-перше, неможливістю врахування всього різноманіття технологічних факторів, які притаманні міським маршрутам при використанні методики [4]. А по-друге, згідно [5] найвагомішими джерелами витрат палива є саме гальмування та розгони автомобіля, які можуть складати до $60 \%$ від загальних витрат палива. В свою чергу 
запровадження експресного сполучення на маршруті №34 призведе до суттєвого скорочення (до 2040\%) паливних витрат.

У якості апробації розробленої моделі були проведені експериментальні дослідження (після кожного рейсу бак автобусів заповнювався «до відстрілу») витрат палива на маршруті №34, які позначені на Рис. 3 символом А. Отримані результати засвідчують достатню відповідність між розрахунковими та експериментальними значеннями (Рис.3). Також про якісну адекватність розробленої розрахункової моделі свідчить порівняльний аналіз впливу довжини перегону на витрати палива автобусів Богдан А092 (на маршруті №34) та ЛіАЗ 677, які були отримані в роботі [6] на підставі повномасштабних експериментальних досліджень (Рис. 4). Обидві характеристики мають схожий гіперболічний характер, а лінійні залежності, які їх апроксимують, майже паралельні між собою.

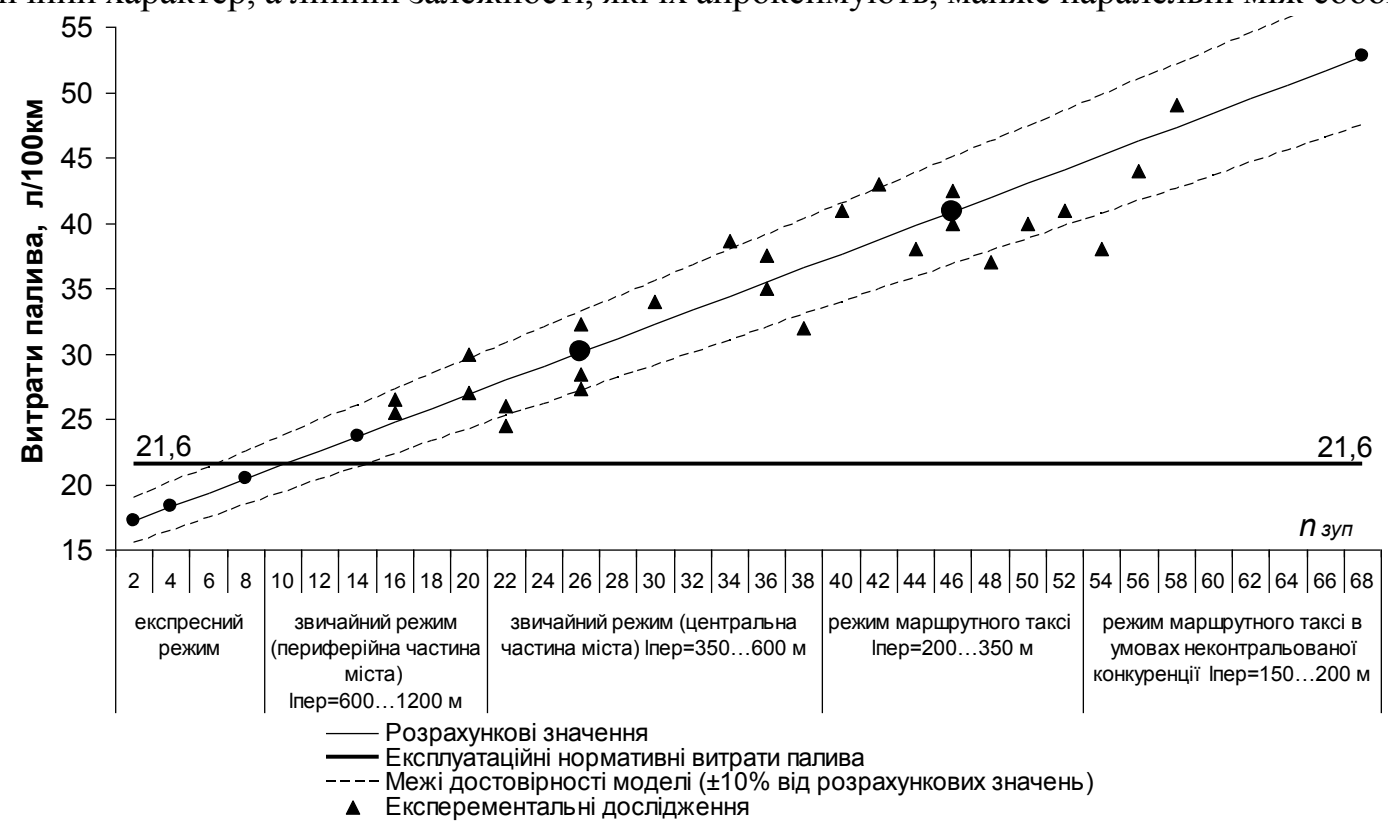

Рисунок 3 - Вплив режиму руху на маршруті №34 на витрати палива автобусів Богдан А092

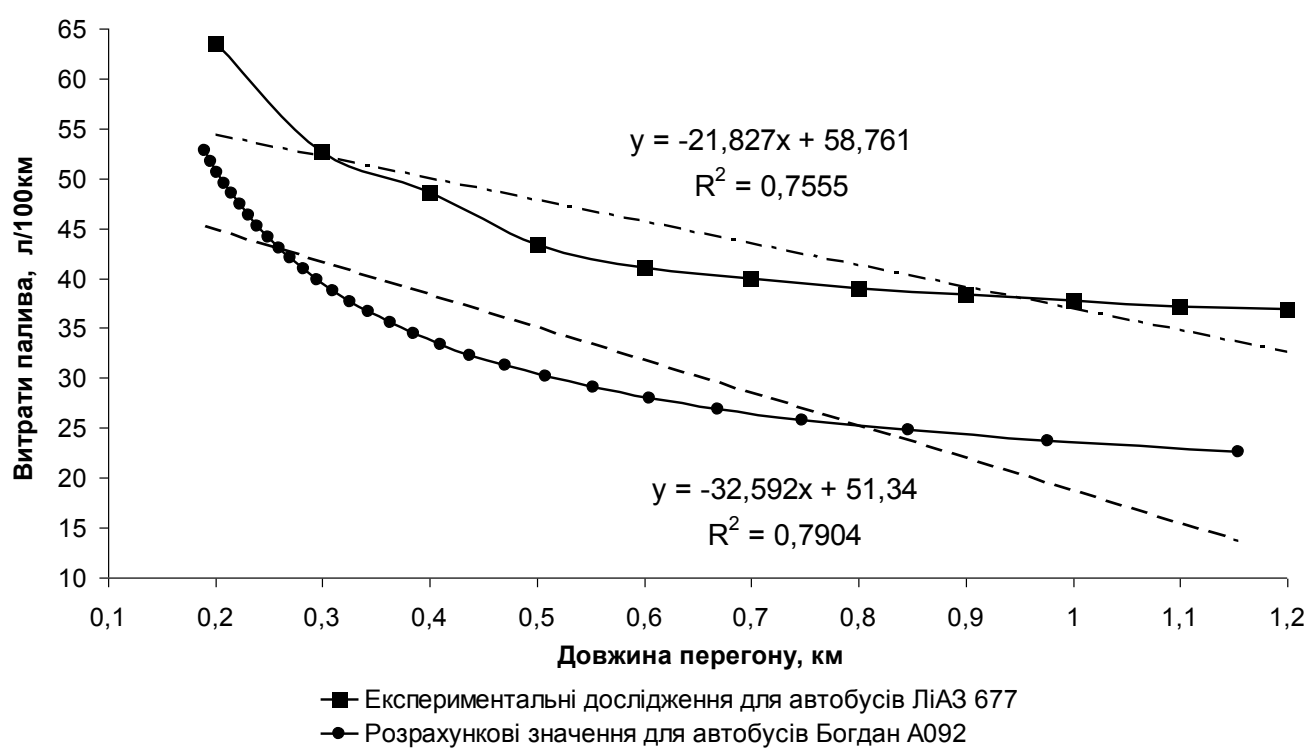

Рисунок 4 - Вплив довжини перегону на витрати палива автобусів Богдан А092 та ЛіАЗ 677

Слід також зауважити, що відмова від експлуатації автобусів на маршруті №34 у режимі маршрутного таксі призведе до зменшення (за рахунок скорочення витрат палива) кількості викидів шкідливих речовин: вуглекислого газу $\left(\mathrm{CO}_{2}\right)$ на 27\%, чадного газу (CO) на 18\%, вуглеводневих сполук (НС) на 10\%, оксидів азоту $\left(\mathrm{N}_{\mathrm{x}} \mathrm{O}_{\mathrm{y}}\right)$ на $32 \%$, діоксиду сірки $\left(\mathrm{SO}_{2}\right)$ на $27 \%$.

Висновки. На базі рівнянь силового та паливного балансів створено розрахункову модель, яка дозволяє дослідити вплив умов експлуатації на процес формування витрат палива міськими автобусами. На підставі результатів обстеження пасажиропотоків на маршруті №34 були розраховані витрати палива для автобусів Богдан А092 для різних режимів руху. Встановлено, що витрати палива 
автобусів, яки працюють у звичайному режимі перевищують нормативні значення [4] на 36\%; а у режимі маршрутного таксі на 86\%. Відмова від експлуатації автобусів на маршруті №34 у режимі маршрутного таксі призведе до зменшення кількості викидів шкідливих речовин на $18-32 \%$.

1. Taran I., Litvin V. Determination of rational parameters for urban bus route with combined operating mode. Transport Problems: international scientific journal. 2018. Vol. 13 (4). P. 157-173.

2. Почему выросла цена на проезд в Днепре: расчеты, траты, тарифы [Электронный pecypc]. URL: https://dengi.informator.ua/2018/03/22/pochemu-vyrosla-tsena-na-proezd-v-dnepre-raschety-traty-tarify (Дата обращения: 22.03.18).

3. Доля В. К. Пасажирські перевезення: [підручник] / В. К. Доля. - Харків: «Вид-во «Форт», 2011. - 504 с.

4. Норми витрат палива і мастильних матеріалів на автомобільному транспорті. - К. : Мінтранс України, 1998. - 45 с.

5. Говорущенко Н.Я. Системотехника транспорта (на примере автомобильного транспорта) / Н.Я. Говорущенко, А.Н. Туренко. -Харьков: РИО ХНАДУ, 1999. - 468 с.

6. Абрамов С.Н. Совершенствование методов разработки нормативов расхода топлива на основе учета технологии движения на автобусних маршрутах: дис. кандидата техн. наук / С.Н. Абрамов. - М., 1983. - 170с.

\section{REFERENCES}

1. Taran I. \& Litvin V. (2018). Determination of rational parameters for urban bus route with combined operating mode. Transport Problems: international scientific journal. 13 (4), 157-173.

2. Pochemu vyirosla tsena na proezd $\mathrm{v}$ Dnepre: raschetyi, tratyi, tarifyi [Elektronnyiy resurs]. URL: https://dengi.informator.ua/2018/03/22/pochemu-vyrosla-tsena-na-proezd-v-dnepre-raschety-traty-tarify (Data obrascheniya: 22.03.18).

3. Dolya V. K. (2011). PasazhirskI perevezennya: [pidruchnik]. HarkIv: «Vid-vo «Fort», 504.

4. (1998) Normi vitrat paliva i mastilnih materialiv na avtomobilnomu transporti. K.: Mintrans Ukrayini, 45.

5. Govoruschenko N.Ya. \& Turenko A.N. (1999). Sistemotehnika transporta (na primere avtomobilnogo transporta). Harkov: RIO HNADU, 468.

6. Abramov S.N. (1983). Sovershenstvovanie metodov razrabotki normativov rashoda topliva na osnove ucheta tehnologii dvizheniya na avtobusnih marshrutah: dis. kandidata tehn. nauk. M., 170.

Литвин В.В., Таран И.А. Влияние режимов движения городских автобусов на топливную экономичность и экологическая безопасность.

В работе обоснована актуальность исследования влияния режимов движения городских автобусов на топливную экономичность и экологическую безопасность. Выполнен анализ работ, посвященных вопросам определения расхода топлива и динамических качеств автомобилей. Установлено, что для городских автобусных перевозок наиболее весомыми факторами, которые влияют на топливную экономичность, являются длина перегона и наполнение салона автобуса. Разработана расчетная модель, которая позволяет исследовать влияние условий эксплуатации на процесс формирования расхода топлива городскими автобусами. На основании результатов обследования пассажиропотоков на маршруте №34 был рассчитан расход топлива для автобусов Богдан А092 для различных режимов движения. Представлены результаты экспериментальных исследований, которые подтверждают адекватность разработанной расчетной модели.

Ключевые слова: расход топлива, длина перегона, режим движения, расчетная модель, экологическая безопасность.

V. Litvin, I. Taran. Effect of traffic conditions of urban buses on the fuel economy and environmental safety.

The paper has substantiated topicality of analysis of effect of traffic conditions of urban buses on the fuel economy and environmental safety. Papers, concerning the problems to determine fuel consumption and dynamic qualities of transportation vehicles, have been analyzed. It has been determined that distance between stops and bus fullness are the most important factors effecting fuel economy. Analytical model, making it possible to analyze effect of operation conditions on the formation of fuel consumption by urban buses, has been developed. Basing upon the analysis of passenger traffic flow in the context of route 34 , fuel consumption for Bohdan A092 bus has been calculated for different traffic conditions. Experimental results, supporting adequacy of the analytical model, have been represented.

Key-words: fuel consumption, distance between stops, traffic condition, analytical model, environmental safety.

ЛИТВИН Вадим Вікторович, старший викладач кафедри «Управління на транспорті», НТУ «Дніпровська політехніка», e-mail: litvin.v.v.79@gmail.com;

ТАРАН Ігор Олександрович, доктор технічних наук, професор, завідувач кафедри «Управління на транспорті», НТУ «Дніпровська політехніка», e-mail: taran7077@ gmail.com.

ЛИТВИН Вадим Викторович, старший преподаватель кафедры «Управления на транспорте», НТУ «Днепровская политехника», e-mail: litvin.v.v.79@gmail.com;

ТАРАН Игорь Александрович, доктор технических наук, профессор, заведующий кафедрой «Управления на транспорте», НТУ «Днепровская политехника», e-mail: taran7077@ gmail.com.

Vadim LITVIN, senior lecturer of Transport Management Department, National Technical University "Dnipro Polytechnic", e-mail: litvin.v.v.79@gmail.com;

Igor TARAN, Doctor of Science in Technology, Professor, Head of Transport Management Department, National Technical University “Dnipro Polytechnic”, e-mail: taran7077@gmail.com.

Стаття надійшла в редакцію 04.05.2019p. 